\title{
INTEGRATED MARKETING COMMUNICATIONS OF COMMERCIAL BANKS IN THE CONDITIONS OF A HIGHLY COMPETITIVE MARKET: ESSENCE AND FORMATION
}

\author{
Mariana Demko', Nataliia Kosar ${ }^{2}$, Nataliia $\mathrm{Kuzo}^{3}$
}

Received: 2021-02-12

Accepted: 2021-04-16

DOI: http://doi.org/10.46489/gpj.2021-1-1-8

\begin{abstract}
In this article, we analyze the dynamics of active operations of several Ukrainian banks. During the last three years, there was a declining trend in the number of commercial banks in Ukraine and their issued loans' size. In order to increase the assets of banking institutions of Ukraine, increase their income, banks need to attract new customers, increase the volume of products purchases by existing customers through active communication activities of commercial banks of Ukraine. The intensification of Internet use by banks opens new opportunities for the sales systems improvement and promotion of their products. The analyzed the main characteristics of the commercial bank marketing policy of communications and the basic principles of integrated marketing banking institutions formation and the mechanism of their implementation, which begins with the collection and analysis of marketing information, based on the mission, corporate and marketing bank goals. We argue that an essential stage in forming integrated marketing communications of the bank is to determine its target audiences, which are much more comprehensive than the bank's target market, a rational combination of individual components of the bank's communication complex. Integrated marketing communications of a commercial bank should aim at forming its image and reputation in the market, taking into account the existing competitive advantages of the bank. We determined that in the conditions of Internet spread, an essential component of the integrated marketing communications of a banking institution is online communications. We formulated the main goals and means of marketing communications realization of the bank on the Internet and developed proposals to improve the efficiency of the bank in social networks.
\end{abstract}

Keywords: commercial bank, market of banking products, organization mechanism of integrated marketing communications of the bank, bank's marketing communications in the Internet

\footnotetext{
${ }^{1}$ Mariana Demko, Postgraduate Student of the Department of Marketing, Faculty of Economics, Ivan Franko National University of Lviv, Universytetska str., 1, 79000 Lviv, Ukraine, e-mail: mariana.demko@lnu.edu.ua ORCID: https://orcid.org/0000-0001-7081-9001

2 Nataliia Kosar, PhD, Associate Professor, Department of Marketing and Logistics, Lviv Polytechnic National University, Bandera str., 12, 79013 Lviv, Ukraine, e-mail: nataliia.s.kosar@lpnu.ua, ORCID: https://orcid.org/0000-0003-0180-2630

${ }^{3}$ Nataliia Kuzo, Senior Teacher, Department of Marketing and Logistics, Lviv Polytechnic National University, Bandera str., 12, 79013 Lviv, Ukraine, e-mail: natalia.y.kyzjo@lpnu.ua; ORCID: https://orcid.org/0000-00030640-3276
} 


\section{ВСТУП}

Основними завданнями у системі маркетингового управління комерційним банком у сучасних умовах $\epsilon$ формування попиту на його продукти та його підвищення внаслідок посилення конкуренції на ринку. Банківські установи намагаються постійно пропонувати на ринку нові продукти, які проте можуть швидко скопіювати банки-конкуренти. У таких умовах особливого значення набуває саме здатність комерційних банків України продемонструвати унікальність клієнтам пропонованих ними продуктів через формування ефективної маркетингової політики комунікацій. Остання $\epsilon$ важливою передумовою для комерційного успіху банку та покращання його конкурентних позицій на ринку. Цифровізація сучасної економіки України вимагає від банківських установ активного використання Інтернету у сфері маркетингових комунікацій.
Метою даної статті є аналіз ринку банківських продуктів України, важливості на ньому маркетингових комунікацій банків, розроблення механізму організації інтегрованих маркетингових комунікацій банківських установ.

\section{РЕЗУЛЬТАТИ}

Ринок банківських продуктів виступає важливою складовою ринкової економіки України. Комерційні банки, що $\epsilon$ основними складовими інфраструктури ринку банківських продуктів, виступають посередниками у перерозподілі фінансового капіталу, формуванні неперервного процесу економічного відтворення, забезпеченні потреб клієнтів щодо примноження їх грошових коштів, задоволенні їх потреби у пропозиції певних грошових коштів. На рис. 1 відображена динаміка кількості комерційних банків України 3 2007 р. до 2020 р.

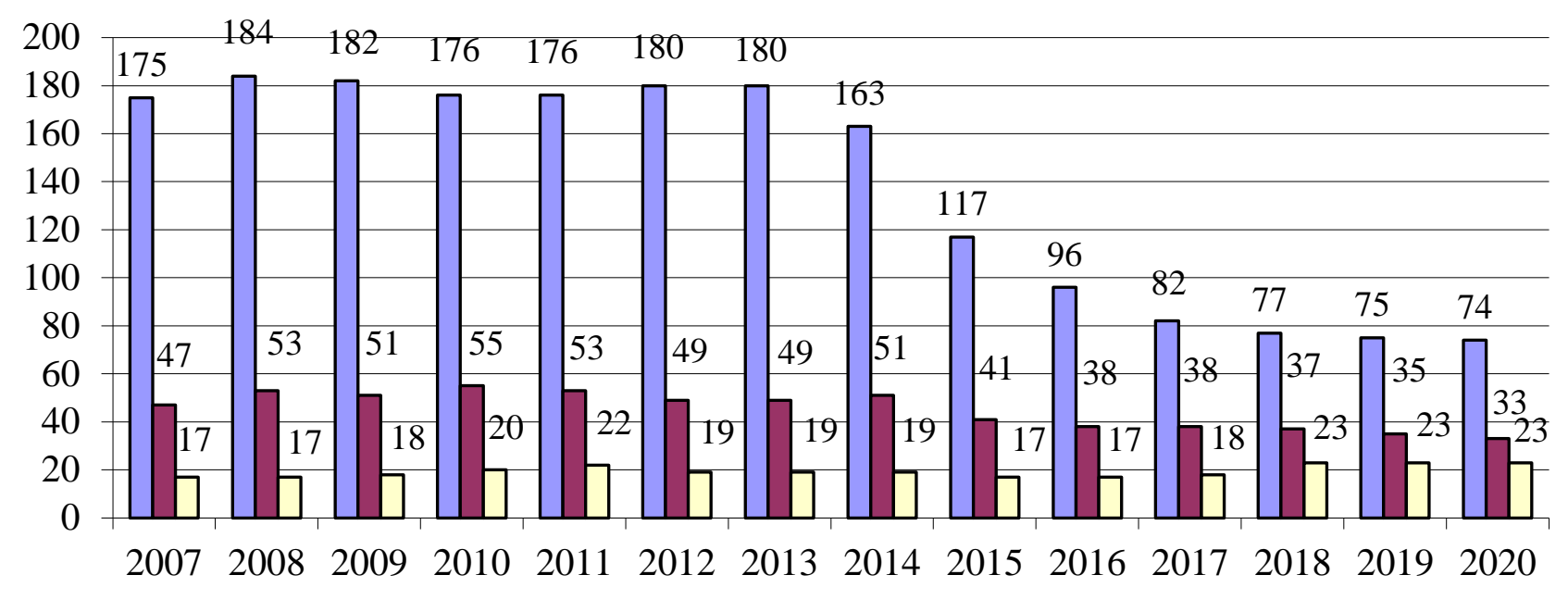

口Кількість діючих банківських установ

口3 них з наявним іноземним капіталом

口Серед них зі 100 \% іноземним капіталом

Рис. 1. Аинаміка кількості банків України за 2007-2020 pp.

Ажерело: (Kilkist bankiv v Ukraini (2008-2020), 2021)

Аналіз рис. 1 свідчить про наявність спадної тенденції щодо кількості комерційних банків України, починаючи
32007 р., між якими посилюється боротьба за залучення уваги клієнтів. 
Протягом першого півріччя 2020 р. банківський сектор в Україні суттєво відчув вплив на свій розвиток проблемних факторів внаслідок існування світової пандемії. Це було обумовлене уповільненням темпів розвитку світової економки, падінням обсягів виробництва та іншими наслідками існування карантинних обмежень в Україні. Проте існуюча криза, хоча і мала вплив на розвиток українського банківського сектору, але не виявилася критичною для нього. Аналіз ринку банківських продуктів України за 2020 р. дозволив встановити наступні тенденції щодо його розвитку (Reitynh finansovoho zdorovia bankiv, 2021):

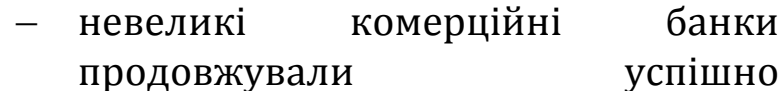
конкурувати за клієнтів та ринкову частку, дотримуючись законодавчо встановлених нормативів щодо функціонування;

- великі банки теж показали значну ефективність використання власних активів;

- скорочувався розрив по показниках фінансового здоров`я, між великими комерційними банками та невеликими.

Прибутковість банківської системи України забезпечують активні операції комерційних банків, зокрема видача кредитів. На рис. 2 подано динаміку виданих комерційними банками України кредитів та сумарно активів.

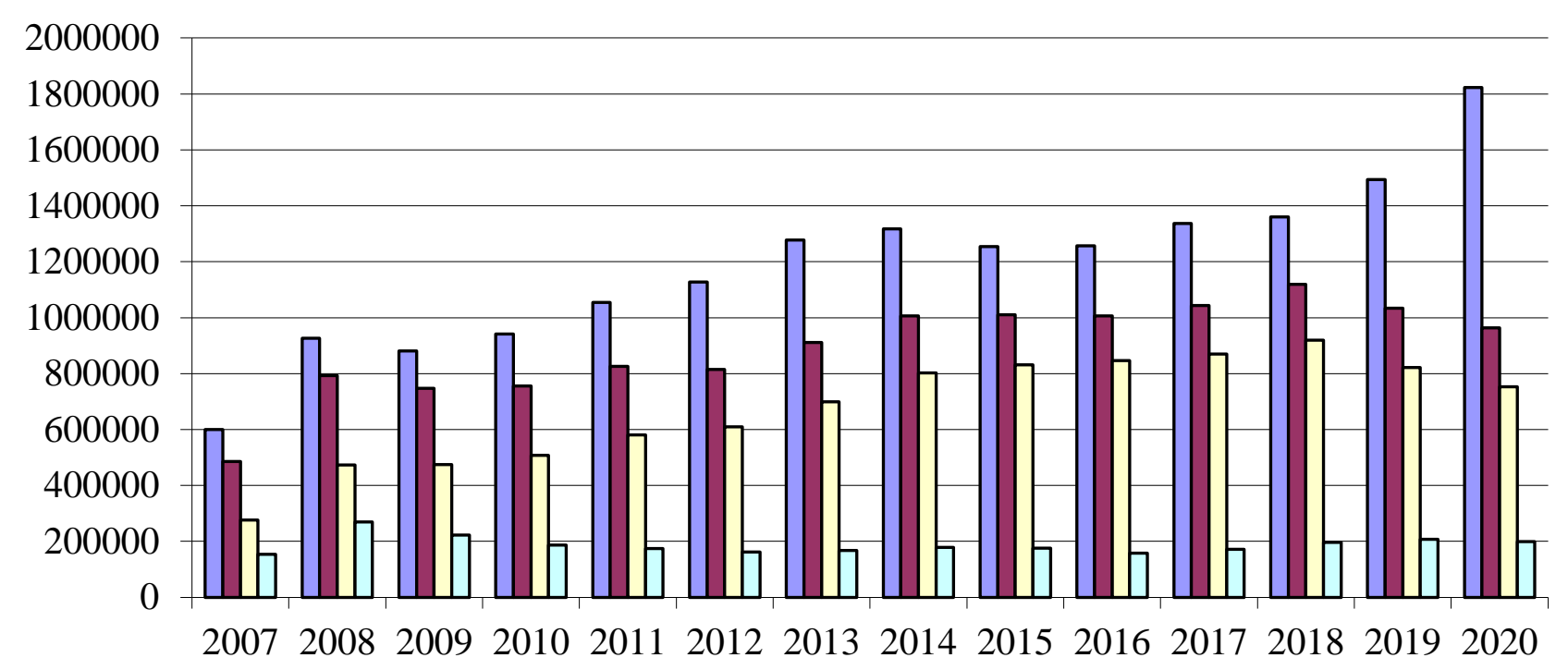

$\square$ Сумарні активи

$\square$ Кредити для суб'єктів господарювання $\square$ Надані банками кредити

口Кредити для фізичних осіб

Рис. 2. Аинаміка виданих комерційними банками України кредитів та сумарних активів, мАн. грн.

Ажерело: (Aktyvy bankiv Ukrainy (2008-2020), 2021)

Аналіз рис. 2 показує, що у 2020 р. величина наданих банками кредитів зменшилася порівняно з 2019 р. на 6,76 $\%$, у т.ч. суб'єктам господарювання - на $8,45 \%$, фізичним особам - на 3,48 \%. Хоча величина сумарних активів банківської системи України у 2020 р. зросла порівняно з 2019 р. на 21,97 \%. Для зростання активів банківських установ України важливим чинником $\epsilon$ залучення нових позичальників за рахунок активних комунікаційних заходів банківських установ України. 
Зростання використання Інтернетбанкінгу обумовили дії банків щодо скорочення їх власної збутової мережі. Наприклад, лише протягом 2019 р. банківські установи України закрили 507 відділень. Важливим завданням у сфері зростання використання банками та клієнтами систем Інтернет-банкінгу $є$ формування надійних систем щодо інформаційного захисту (Kosar N.S., Kuzo N.Ye. \& Bilyk I.I., 2020). Одночасно Інтернет відкриває нові можливості для вдосконалення системи просування банківських продуктів із незначними витратами.

У літературі 3 маркетингу існують різні визначення сутності маркетингової політики комунікацій комерційних банків, які узагальнено подано у Маслової Н.О. та Хоменко Б.А. (2016). У подальшому ми будемо орієнтовані на визначення маркетингової політики комунікацій, яке подане Лютим I.O. відповідно до якого, вона включає у себе комплекс заходів, що $\epsilon$ спрямованими на забезпечення інформування потенційних та наявних клієнтів про даний банк i його продукти, їx переконання у доцільності скористатися ними та нагадування їм щодо складових продуктового портфелю комерційного банку на ринку. Проте у даному визначенні не враховується, що маркетингові комунікації банківської установи спрямовані також і на інші цільові аудиторії, такі як посередники, конкуренти, акціонери та органи держуправління, власний персонал організації тощо (Volokhata V. Ye., 2019), метою яких $\epsilon$ формування передусім позитивного іміджу банківської установи та іï бренду. Тому одночасно при визначені сутності маркетингової політики комунікацій банківської установи слід відзначити, що вона відповідно до визначення Норіциної Н.I. та Ламбена Ж.-Ж. має бути спрямована також на формування бренду банку, підвищення його капіталу через формування інформаційних потоків, спрямованих на різних суб'єктів ринку та контактні аудиторії.

Маркетингова політика комунікацій банківських установ повинна бути спрямована на формування єдиного образу та іміджу банку через ії інтегрування. Концепція інтегрованих маркетингових комунікацій (IMK) спрямована на проведення ретельної організації та координації діяльності різноманітних каналів комунікацій 3 метою формування банком чіткого, а також послідовного і переконливого його сприйняття цільовими аудиторіями (Mokliak M.V., Lytvyn I.V. \& Yarmosh H.V., 2015). При усій різноманітності щодо використання інструментів та підходів до розроблення інтегрованих маркетингових комунікацій банківських установ можна визначити такі основні принципи щодо їх формування (Romanenko 0.0., 2010):

- синергізм, що передбачає організацію взаємної підтримки усіх елементів ІМК та проведення їх послідовної координації. Взаємні комунікаційні дії банківської установи забезпечують більший ефект для неї (синергічний), ніж просте їх складання;

- відкритість до співробітництва 3 партнерами по бізнесу, можливість утворювати 3 ними альянси, проводити оптимізацію маркетингових бюджетів. Важливою $\epsilon$ горизонтальна комунікація 3 ринковими партнерами, яка робить бізнес більш стійким до зовнішніх впливів;

- оперативність, тобто готовність банківських установ використовувати як спеціально створені, так і ті, що випадково виникають події для організації стратегічних комунікацій у межах 
маркетингу подій чи вірусного маркетингу.

Отже під інтегрованими маркетинговими комунікаціями банку будемо розуміти вибір, використання ним та контроль над усіма засобами маркетингових комунікацій, що забезпечить ефективну взаємодію між комерційним банком та його цільовими аудиторіями комунікації; при цьому усі повідомлення, що надходять від банку, мають бути інтегрованими, а отже, односпрямованими та узгодженими i повинні сприяти досягненню єдиної комунікаційної мети банку - мінімізації сфери розбіжності економічних

інтересів банківської установи та його цільових аудиторій впливу, формуванню іміджу банку, 3 виникненням синергічного ефекту при взаємодіi складових маркетингових комунікацій, коли кожний структурний інструмент у своїй синергічній єдності забезпечує вагомий позитивний ефект для успішного провадження банківської діяльності.

3 метою впливу на свої цільові аудиторії комерційні банки можуть використовувати різні інструменти системи маркетингових комунікацій, характеристику яких подано у табл. 1.

Таблиця 1

Характеристика основних складових системи маркетингових комунікацій комерційного банку

\begin{tabular}{|c|c|c|}
\hline $\begin{array}{c}\text { Найменування } \\
\text { складової }\end{array}$ & Сутність & Основні завдання \\
\hline Реклама & $\begin{array}{llrr}\text { Являє собою } & \text { платну } & \text { форму } \\
\text { неперсонального } & \text { подання } & \text { та } \\
\text { просування } & \text { продуктів i послуг, яку } \\
\text { замовляє та } & \text { фінансує } & \text { певний } \\
\text { комерційний банк } & & \end{array}$ & $\begin{array}{l}\text { Спонукання до закупівлі } \\
\text { продуктів певних клієнтів, } \\
\text { інформування про них, } \\
\text { формування кола постійних і } \\
\text { лояльних клієнтів, формування } \\
\text { іміджу банку }\end{array}$ \\
\hline $\begin{array}{l}\text { Зв'язки } \\
\text { громадськістю }\end{array}$ & 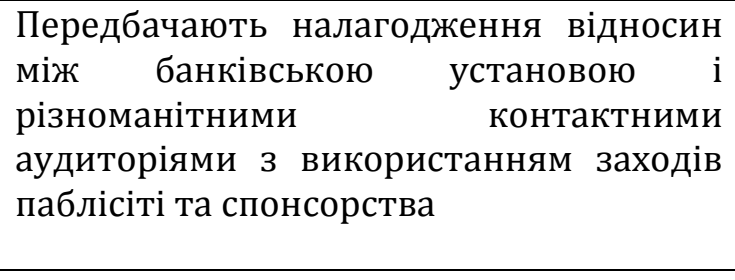 & $\begin{array}{l}\text { Формування вигідної для банку } \\
\text { репутації, його позитивного } \\
\text { іміджу, з однієї сторони, а також } \\
\text { усунення або попередження } \\
\text { небажаних для нього чуток, } \\
\text { пліток чи дій - з іншої сторони }\end{array}$ \\
\hline $\begin{array}{l}\text { Заходи } \\
\text { стимулювання } \\
\text { збуту }\end{array}$ & $\begin{array}{l}\text { Являють собою одноразові заходи } \\
\text { заохочення клієнтів до закупівлі тих чи } \\
\text { інших продуктів та послуг даного банку. } \\
€ \text { привабливими для клієнтів }\end{array}$ & $\begin{array}{lr}\text { Короткочасне } & \text { спонукання } \\
\begin{array}{l}\text { клієнтів } \\
\text { банківських } \\
\text { послуг }\end{array} & \text { продуктів } \\
\end{array}$ \\
\hline $\begin{array}{l}\text { Прямий } \\
\text { маркетинг }\end{array}$ & \begin{tabular}{llr}
\multicolumn{2}{l}{ Передбачає } & \multicolumn{2}{c}{ використання } & банком \\
різних інструментів & маркетингових \\
комунікацій & для & \multicolumn{2}{c}{ організації } \\
безпосереднього & \multicolumn{2}{c}{ спілкування } \\
клієнтами & &
\end{tabular} & 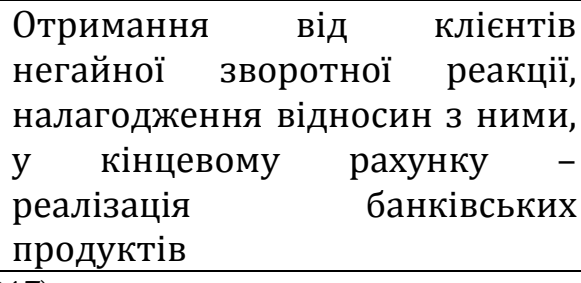 \\
\hline
\end{tabular}

Ажерело: розроблено на основі (Milinevskyi V.H. \& Klimova I. O., 2017)

Правильна організація інтегрованих маркетингових комунікацій є однією 3 передумов успішної прибуткової діяльності банку. При цьому слід враховувати, що їх інструменти мають бути узгодженими та враховувати всі особливості специфіки діяльності конкретної банківської установи, її цілі і завдання, політику і стратегію, а також потреби та інтереси клієнтів (Demko М.Yа., 2018).

Сьогодні важливим завданням для комерційних банків $є$ i підвищення їх репутації. Досягнути цього банківські 
установи можуть через свою участь у реалізації регіональних соціальних програм, підтримку громадських організацій та різноманітних суспільних рухів, приймаючи участь у вирішенні низки екологічних проблем, у організації проведення професійних конкурсів, рейтингів, сертифікації 3 метою підтвердження високої якості своїх продуктів із подальшим поширенням отриманих результатів (Kosar N.S., Kuzo N.Ye. \& Bilyk I.I., 2019).

Проте розроблення системи інтегрованих маркетингових комунікацій повинно розпочинатися передусім із збирання та аналізу маркетингової інформації. Пропонуємо механізм організації інтегрованих маркетингових комунікацій у діяльності банків як взаємодію певних елементів - Додаток 1.

Для комерційних банків особливої актуальності сьогодні набувають маркетингові комунікації, які не вимагають залучення значних фінансових ресурсів з використанням Інтернету. Цілі і засоби реалізації маркетингових комунікацій в Інтернет подано в табл. 2

Таблиця 2

Цілі і засоби реалізації маркетингових комунікацій в Інтернеті

\begin{tabular}{|c|c|c|}
\hline \multicolumn{3}{|c|}{ Цілі маркетингових комунікацій в Інтернеті } \\
\hline Продуктове просування & Іміджеве просування & Збільшення трафіку \\
\hline $\begin{array}{l}\text { Фактори відгуку: } \\
\text { - кількість звернень та } \\
\text { відвідувань; } \\
\text { - кількість клієнтів } \\
\text { загалом; } \\
\text { - відомість банку та } \\
\text { відношення до нього } \\
\end{array}$ & $\begin{array}{l}\text { Фактори відгуку: } \\
\text { - відомість банку та відношення } \\
\text { до нього; } \\
\text { - кількість клієнтів загалом; } \\
\text { - кількість лояльних клієнтів; } \\
\text { - приріст прибутку банку }\end{array}$ & $\begin{array}{l}\text { Фактори відгуку: } \\
\text { - кількість відвідувачів; } \\
\text { - кількість звернень на web- } \\
\text { сайт банку; } \\
\text { - кількість клієнтів загалом; } \\
\text { - кількість лояльних клієнтів; } \\
\text { - відомість банку. }\end{array}$ \\
\hline \multicolumn{3}{|c|}{ Засоби реалізації маркетингових комунікацій в Інтернеті } \\
\hline $\begin{array}{l}\text { Просування з метою } \\
\text { залучення аудиторії }\end{array}$ & $\begin{array}{c}\text { Просування з метою зростання } \\
\text { доходів банку }\end{array}$ & $\begin{array}{r}\text { Просуван } \\
\text { формув }\end{array}$ \\
\hline $\begin{array}{l}\text { - пошукова } \\
\text { оптимізація; п підтримка } \\
\text { - актуальності } \\
\text { інформації на web-сайті } \\
\text { банку та його сторінках } \\
\text { у соціальних мережах }\end{array}$ & $\begin{array}{l}\text { - пошукова реклама (текстові } \\
\text { блоки, медійний контент); } \\
\text { - неконтекстна реклама } \\
\text { (текстові модулі, банери - } \\
\text { статичні і анімація, Rich-медіa); } \\
\text { - новини та прес-релізи; } \\
\text { - статті на замовлення; } \\
\text { - пряма поштова реклама }\end{array}$ & $\begin{array}{l}\text { - іміджеві статті; } \\
\text { - новини та прес-релізи; } \\
\text { - заходи подійного } \\
\text { маркетингу; } \\
\text { - інформація від експертів; } \\
\text { - прихована реклама в } \\
\text { опитуваннях; } \\
\text { - робота на форумах; } \\
\text { - підписка }\end{array}$ \\
\hline
\end{tabular}

Ажерело: розроблено на основі (Lebedenko M.S., 2008)

Маркетингова діяльність комерційного банку, $\mathrm{y}$ т.ч. і його маркетингові комунікації, здійснюються керуючою підсистемою банку, зокрема його маркетинговою службою, яка формує мету маркетингових комунікацій відповідно до корпоративних цілей та місії банку, розроблених ним маркетингових стратегій (табл. 3) та сформованих програм лояльності.
Сьогодні актуальним інструментом просування банку $є$ соціальні мережі. Відгуки у них $€$ важливими для потенційних клієнтів при виборі ними банків. За допомогою соціальних мереж досліджувана банківська установа може відслідковувати і реакцію клієнтів на свої банківські продукти, і негативні відгуки про свою діяльність та оперативно на них реагувати. 
Таблиця 3

Основні цімі банку при розробці своєї вцасної маркетингової стратегії

\begin{tabular}{|c|c|c|}
\hline ементи фор & $\begin{array}{r}\text { Цілі бан } \\
\text { розроб } \\
\text { власної }\end{array}$ & ові цілі \\
\hline 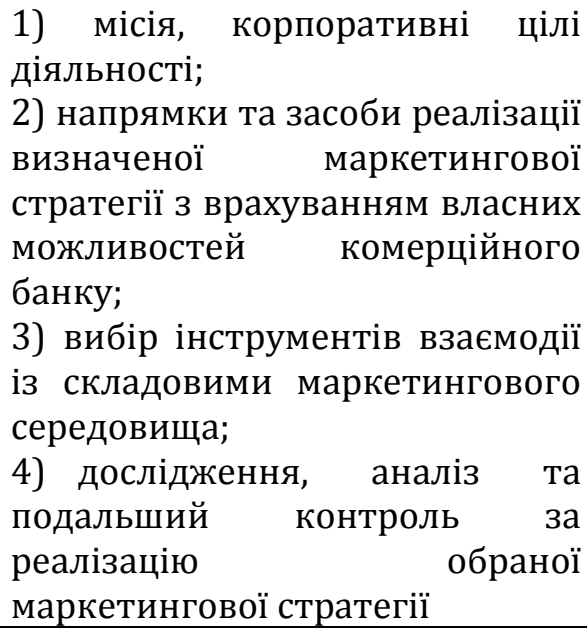 & $\begin{array}{l}\text { 1) обгрунтування } \\
\text { цілей одного } \\
\text { спрямування; } \\
\text { 2) визначення } \\
\text { завдань,які } \\
\text { необхідні для } \\
\text { досягнення } \\
\text { поставлених } \\
\text { цілей; } \\
\text { 3) встановлення } \\
\text { маркетингових } \\
\text { інструментів для } \\
\text { досягнення цілей }\end{array}$ & 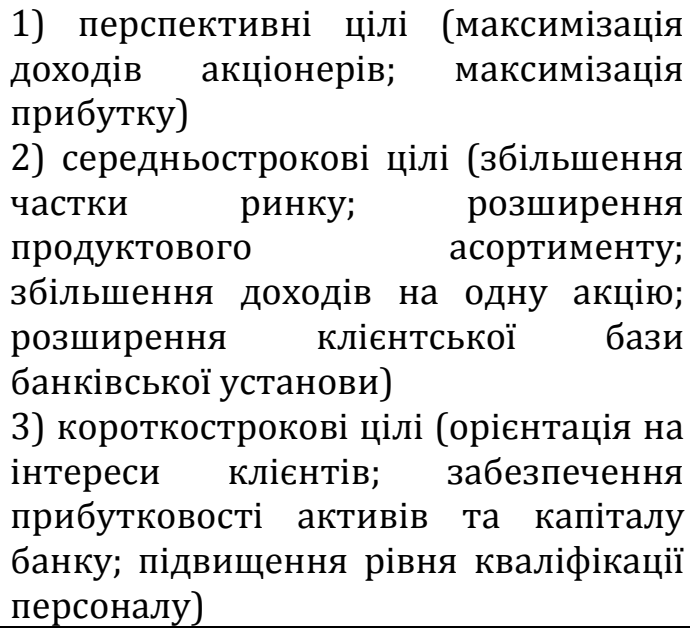 \\
\hline
\end{tabular}

Ажерело: розроблено на основі (Shkvyria N. O., 2016)

Підвищити ефективність функціонування банківської установи у соціальних мережах можна за допомогою заходів, наведених у табл. 4.

Таблиця 4

Заходи підвищення ефективності діяльності банків у соціальних мереж

\begin{tabular}{|c|c|}
\hline Заходи & Напрями використання \\
\hline $\begin{array}{l}\text { Формування } \\
\text { банку }\end{array}$ & $\begin{array}{l}\text { Обговорення важливих тем, переваг і недоліків певних } \\
\text { банківських продуктів, вивчення побажань клієнтів }\end{array}$ \\
\hline $\begin{array}{l}\text { Активізація } \\
\text { блогосферою }\end{array}$ & $\begin{array}{l}\text { Інформування клієнтів, формування та підтримання } \\
\text { інтересу до бренду банку, управління споживчими } \\
\text { перевагами клієнтів }\end{array}$ \\
\hline $\begin{array}{lr}\text { Формування } \\
\text { брендингу топ менедх }\end{array}$ & Підвищення іміджу банківської установи \\
\hline $\begin{array}{l}\text { Проведення нестандартних } \\
\text { активностей банку }\end{array}$ & $\begin{array}{l}\text { Використання у соціальних мережах інтерактивних та } \\
\text { медійних елементів, зокрема вірусного маркетингу, } \\
\text { для привернення уваги до банку }\end{array}$ \\
\hline $\begin{array}{l}\text { Заходи у сфері репутаційного } \\
\text { менеджменту }\end{array}$ & $\begin{array}{l}\text { Використання відгуків клієнтів, які } \\
\text { співпрацею з банком, та лідерів думок }\end{array}$ \\
\hline
\end{tabular}

Ажерело: (Bashynska I. O., 2012)

\section{ВИСНОВКИ}

Ринок банківських продуктів виступає важливою складовою ринкової економіки України, який може суттєво впливати на функціонування інших товарних ринків. Існуюча криза, хоча i мала вплив на розвиток українського банківського сектору, але не виявилася критичною для нього. Проте проведений аналіз засвідчив, що протягом трьох останніх років існує спадна тенденція стосовно кількості комерційних банків України та величини виданих ними кредитів. 3 метою зростання активів банківських установ України, збільшення їх доходів важливим $\epsilon$ залучення банками нових клієнтів, збільшення обсягів закупівлі продуктів існуючими клієнтами за 
рахунок активних комунікаційних заходів комерційних банків України. Активізація використання банками Інтернету відкриває нові можливості для вдосконалення систем збуту та просування їх продуктів. У сучасних умовах комерційні банки України повинні використовувати інтегровані маркетингові комунікації, що повинні бути спрямованими на формування їх іміджу та репутації на ринку, враховувати існуючі конкурентні переваги банку. У статті подано механізм їх реалізації, що розпочинається із збирання та аналізу маркетингової інформації, базується на визначеній місії, корпоративних та маркетингових цілях банку. Встановлено, що важливим етапом

\section{References}

Aktyvy bankiv Ukrainy (2008-2020) (2021). URL : https://index.minfin.com.ua/ ua/banks/stat/active.

Bashynska, I. O. (2012). Marketynhovi komunikatsii pidpryiemstva u sotsialnykh merezhakh. Ekonomichni nauky. Seria: Ekonomika ta menedzhment, 9(1.1). 36-41.

Bashynska, I.O. (2012). Marketynhovi komunikatsii innovatsiino-aktyvnykh promyslovykh pidpryiemstv: formuvannia, intehratsiia, rozvytok: monohrafiia. Donetsk, 199 s.

Demko, M.Ya. (2018). Osoblyvosti orhanizatsii bankivskoho marketynhu $\mathrm{V}$ Ukraini. Finansova systema krainy: tendentsii ta perspektyvy rozvytku: Materialy V Mizhnarodnoi naukovopraktychnoi Internet-konferentsii 11-12 zhovtnia 2018 roku. Ostroh. 70-73.

Kilkist bankiv v Ukraini (2008-2020) (2021). URL : https://index.minfin.com.ua/ ua/banks/stat/count.

Koretska, S. O. (2011). Osoblyvosti rozrobky konkurentnoi stratehii komertsiinoho banku na rynku tsinnykh paperiv. Investytsii: praktyka ta dosvid, 23. 15-18. формування

інтегрованих маркетингових комунікацій банку $\epsilon$ визначення ним цільових аудиторій, які $\epsilon$ значно ширшими ніж цільовий ринок банківської установи, раціональне поєднання окремих складових комунікаційного комплексу банку, що відрізняється за ефективністю для різних цільових аудиторій. Визначено, що в умовах поширення Інтернету важливою складовою інтегрованих маркетингових комунікацій банківської установи $є$ онлайн комунікації. У роботі подано основні цілі та засоби реалізації маркетингових комунікацій банку в Інтернеті, розроблено пропозиції щодо підвищення ефективності функціонування банку у соціальних мережах.

Kosar, N.S., Kuzo, N.Ye. \& Bilyk, I.I. (2019). Kompleks marketynhu u pidvyshchenni konkurentospromozhnosti komertsiinykh bankiv Ukrainy $\mathrm{u}$ suchasnykh umovakh. Naukovyi visnyk Mukachivskoho derzhavnoho universytetu. Seriia Ekonomika, 2 (12). 67-72.

Kosar, N.S., Kuzo, N.Ye. \& Bilyk, I.I. (2020). Rynok bankivskykh produktiv Ukrainy: tendentsii ta perspektyvy rozvytku. Economy, finance, law: current problems and development prospects: collective monograph, Prague. 27-38.

Lebedenko, M.S. (2008). Stratehii marketynhovykh kominukatsii v Interneti. Visnyk Natsionalnoho universytetu "Lvivska Politekhnika", 633. 394-402.

Maslova, N.O. \& Khomenko, B.A. (2016). Osoblyvosti komunikatsiinoi polityky bankiv Ukrainy. Pidpryiemnytstvo ta innovatsii, 2. 108-117.

Milinevskyi, V.H. \& Klimova, I. O. (2017). Marketynhova polityka komunikatsii na suchasnomu pidpryiemstvi. URL : http://eprints.zu.edu.ua/24992/1/Milinev skij.PDF. 
Mokliak, M.V., Lytvyn, I.V. \& Yarmosh, H.V. (2015). Marketynhovi komunikatsii komertsiinoho banku. Naukovyi visnyk Khersonskoho derzhavnoho universytetu. Ser. : Ekonomichni nauky, 10(2). 107-110.

Rakhman, M. S. \& Manhushev, D. V. (2016). Marketynhovi innovatsii yak zasib vdoskonalennia bankivskykh posluh Ukrainy. Visnyk Kharkivskoho natsionalnoho universytetu imeni $V . \quad N$. Karazina. Seriia "Ekonomichna", 90. 51-63.

Reitynh finansovoho zdorovia bankiv. Reitynh bankiv Ukrainy za rezultatamy pershoho pivrichchia 2020 roku. (2021). URL : http://icps.com.ua/reytynh-bankivukrayiny---rezultaty-pivrichchya-2020roku.

Romanenko, O.O. (2010). Sutnist ta protses formuvannia intehrovanykh marketynhovykh komunikatsii. The
Economic Messenger of the NMU, 1. 112119.

Romanenko, 0.0. (2013). Intehrovani marketynhovi komunikatsii: sutnist, kharakterystyka ta osoblyvosti formuvannia. Zbirnyk naukovykh prats Natsionalnoho universytetu derzhavnoi podatkovoi sluzhby Ukrainy, 1. 187-196.

Shkvyria, N. O. (2016). Marketynhova stratehiia rozvytku komertsiinykh bankiv. Visnyk Berdianskoho universytetu menedzhmentu i biznesu, 2 (34). 62-65.

Vartsaba, V.I. \& Diulai, Ye.V. (2014). Marketynhova stratehiia rozvytku banku: elementy ta etapy rozrobky. Naukovyi visnyk Uzhhorodskoho universytetu. Seriia Ekonomika, 3 (44). 106-110.

Volokhata, V. Ye. (2019). Sutnist ta rol komunikatsiinoi polityky banku $\mathrm{V}$ suchasnykh umovakh. Biznesinform, 6. 234239. 


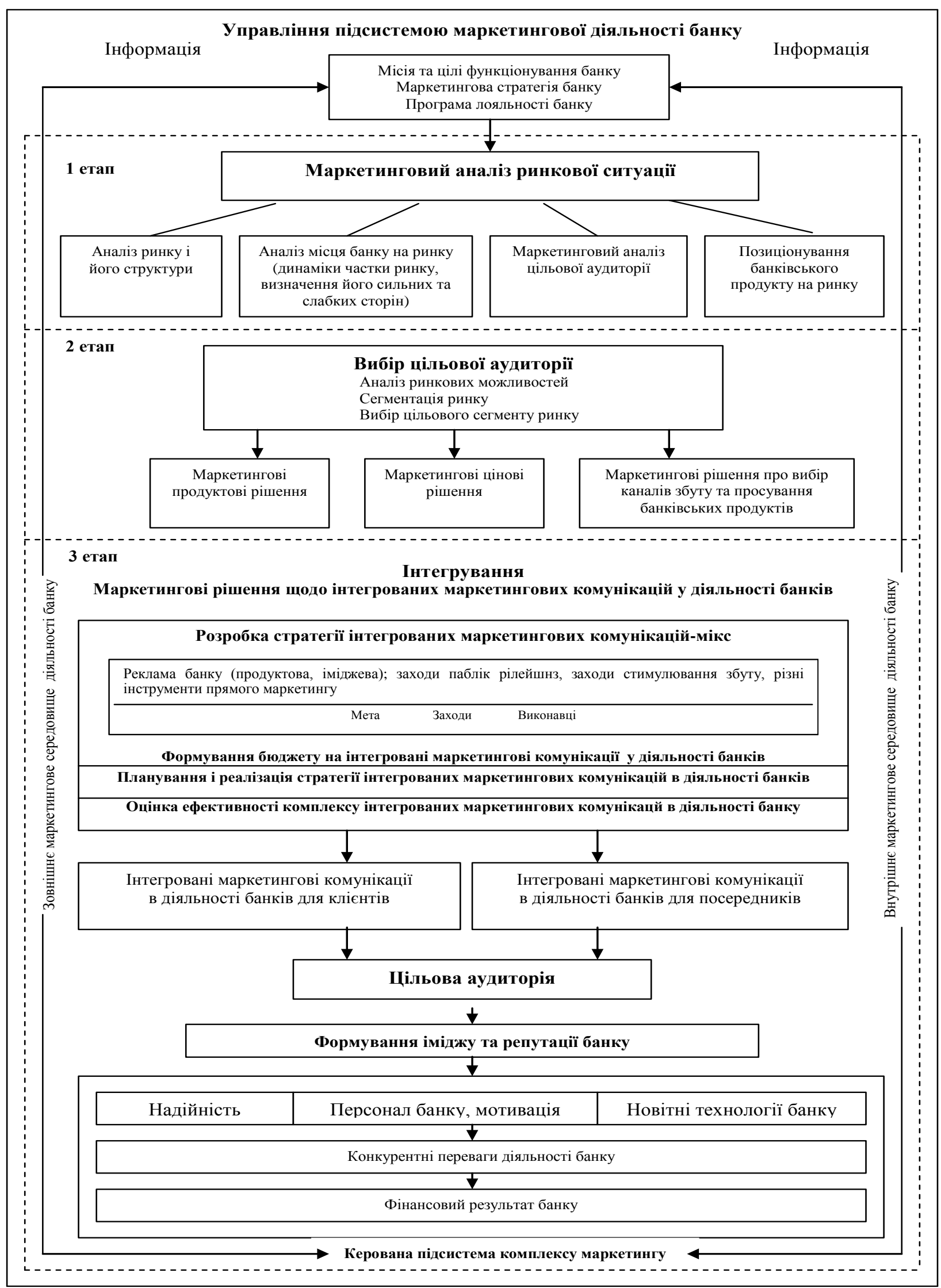

Аодаток 1. Механізм організації інтегрованих маркетингових комунікацій у діямьності комерційних банків

Ажерело: розроблено на основі (Romanenko O.O., 2013, Bashynska I.O., 2012, Rakhman M. S. \& Manhushev D. V., 2016 